\title{
Hybrid Law and Culinary Metaphor : Empty Coquetting or Something Else?
}

\section{Husa, Jaakko}

Routledge

2019-12-06

Husa, J 2019 , Hybrid Law and Culinary Metaphor : Empty Coquetting or Something Else? in S P Donlan \& J Mair (eds), Comparative Law : Mixes, Movements, and Metaphors . 1 edn , Routledge, London, pp. 171-182.

http://hdl.handle.net/10138/330645

unspecified

acceptedVersion

Downloaded from Helda, University of Helsinki institutional repository.

This is an electronic reprint of the original article.

This reprint may differ from the original in pagination and typographic detail.

Please cite the original version. 


\section{Hybrid Law and Culinary Metaphor - Empty Coquetting or Something Else?}

Jaakko Husa

'by far the greatest thing is the use of metaphor'

Aristotle, Poetics ${ }^{1}$

\section{Introduction}

Scholars in different academic fields follow different modes of writing across disciplines and fields of study. In short, what makes perfectly decent scholarly writing in chemistry might be regarded as grossly out of place in political philosophy. Yet, it would be an exaggeration to argue that there could not be significant similarities when it comes to the academic texts produced by scholars. For instance, there are clear structural similarities in academic research texts; it is commonplace to start with an introduction and to end with a conclusion. However, it would be a mistake to assume that even within a certain field or discipline, all of the authors would write in a similar style. Perhaps a leopard cannot change its spots, but not all leopards are similar.

Accordingly, in law as an academic discipline there are different styles of writing depending on the subfield and purpose of the text. Legal historians, legal philosophers, doctrinalists or comparatists tend to compose their texts by using different styles. Also, the purpose of a text is a meaningful factor because a vivid and heavily theory-laden style may work wonderfully in, for example, a legal theoretical or law and literature type of an analysis, whereas using a similar style in a doctrinal introductory textbook would quite likely end in an epic failure. For

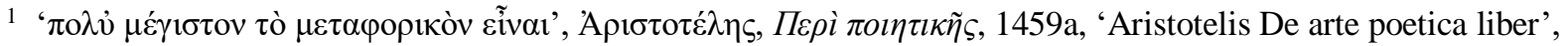
in Rudolf Kassel (ed) Oxford Classical Texts (Oxonii (Oxford), E Typographeo Clarendoniano (Clarendon Press) 1965) (source: Perseus Digital Library, http://perseus.tufts.edu). For Aristotle, being a master of metaphor was something that cannot be learnt from others and, moreover, it is also a sign of literary genius.
} 
this reason, a metaphor loving doctrinalist might soon end up having a rather limited readership indeed.

In the same fashion, comparative law as an academic discipline seems to have its own conventions when it comes to composing different scholarly texts. Consequently, some of the authors have followed the conventions of doctrinal legal writing, whereas others have been influenced by other disciplines like historiography, philosophy or economics. ${ }^{2}$ One curious feature in comparative law language, used by some but certainly not by all scholars, has been the use of metaphors to express ideas, findings and conclusions. But what actually is a metaphor, and how well does it fit into academic comparative law? According to the OED, a metaphor is 'a figure of speech in which a name or descriptive word or phrase is transferred to an object or action different from, but analogous to, that to which it is literally applicable'. 3

In my view, there is a reason why comparatists in particular use metaphors in their writing. This reason is found, it will be argued in this paper, in the comparative nature of the research. In essence, metaphor is a comparison between two things; so it is based on resemblance or similarity of certain qualities without using 'like' or 'as'. In other words, metaphor is not merely a rhetorical device belonging to certain comparatists' personal writing style, but it is an intrinsic part of the attempt to think comparatively. In essence, as defined by Kenneth Burke, metaphor is a 'device for seeing something in terms of something else'. ${ }^{4}$ And, importantly, comparatists always see something else, i.e. foreign laws and legal cultures that are different than their own. ${ }^{5}$

This brief paper discusses the use of metaphor in comparative law by looking at an example from macro-comparative law by Esin Örücü, who has used culinary terms as metaphors while discussing mixed legal systems. The purpose of the following analysis is to illustrate

\footnotetext{
${ }^{2}$ For example, texts from Gunter Frankenberg or Pierre Legrand are also stylistically very different from the texts of Rodolfo Sacco or Reinhard Zimmermann.

${ }^{3}$ Oxford University Press, 'Metaphor' (OED Online March 2016). 〈www.oed.com/view/Entry/117328?redirectedFrom=metaphor〉 accessed 22 April 2016. Of course, this definition basically relies on Aristotle's definition from Poetics (1457b): 'metaphor is the application of a

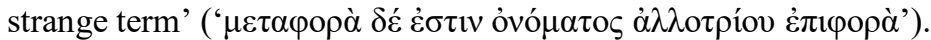

${ }^{4}$ Kenneth Burke, A Grammar of Motives (Berkeley, University of California Press 1969) 503.

${ }^{5}$ Finn Makela speaks of domain mapping, which refers to the fact that metaphors should be seen as speech acts that propose a hypothesis of similarity between two separate domains, see Finn Makela, 'Metaphors and Models in Legal Theory’ (2011) 52 Les Cahiers de droit 397.
} 
particular epistemic benefits of using metaphors in comparative legal literature. Accordingly, it will be argued that metaphors have a special place especially in comparative law literature.

This paper is structured as follows: after this short introduction (section 1), the context of macro-comparative law is explained (section 2). This is followed by a concrete example of metaphorical conceptualisation concerning mixed legal systems (section 3). The final part (section 4) contains a theoretical conclusion on the use of metaphors in macro-comparative law.

\section{About macro-comparative law}

In the theory of comparative law, law groups, legal families, legal cultures and legal traditions are frequently discussed. ${ }^{6}$ Such classifications mainly refer to whole systems, and they represent what is called macro-comparison. Other comparative typologies with a lower abstraction level are built around different substantive sectors of law, like, for example, in comparative constitutional study where as a result of comparison different typologies of models for controlling the constitutionality of laws can be presented. Now, when constructing legal families, the comparatist tries to illustrate the general nature of legal cultural phenomena and the reasons for their manifestations. This is how we classify legal systems into Roman-Germanic (civil law) or common law systems, or how we regard Nordic law as a separate legal family that is legal-culturally closer to the legal cultural sphere of civil law rather than common law. ${ }^{7}$ So, in essence, legal families or other macro-constructs are conceptual and theoretical tools for outlining the core content of a foreign legal system in a very broad and generalising manner. ${ }^{8}$

In macro-comparison, contrasting takes place between legal systems or even between legal families. Accordingly, the levels of abstraction and generalisation are both very high. Macrocomparison does not concentrate on individual legal rules, cases, institutions or concrete problems and the ways to solve them. Comparison may, for example, be aimed at issues that concern legislative methods, the style of writing provisions, the systematisation and division

\footnotetext{
${ }^{6}$ About the distinction between micro-comparison and micro-comparison see, eg, Konrad Zweigert and Hein Kötz, An Introduction to Comparative Law (Oxford, 2 edn, Oxford University Press 1998) 4-5.

7 Jaakko Husa, A New Introduction to Comparative Law (Oxford, Hart Publishing 2015) 25.

8 ibid 225-229.
} 
of the different fields of law and the doctrine of legal sources, or even the style of entire legal systems, i.e. legal cultural features characteristic of them. ${ }^{9}$ Today, the two most important and virtually overarching legal families are civil law and common law. ${ }^{10}$ However, not all systems can be classified as civil law or common law and this poses an epistemic challenge for macro-comparatists. This challenge is caused by hybridity, which in this case refers to a mixture of different elements resulting in a mixed composition of rules, principles and institutions whose elements are derived from different legal families. ${ }^{11}$

To clarify the above, mixed legal systems (or hybrid legal systems) refer to systems that simultaneously contain key-characteristics of other legal families. Reasons for hybridity are always related to legal history, yet, each legal system has had different routes to hybridity. For example, together with British imperialism, common law spread also to areas where other types of law (indigenous, traditional and religious) had earlier been used. If the law that had preceded common law was legal-culturally strong, little by little systems were formed where there were features of both local law and common law. In some well-known cases, like Louisiana and Quebec, mixed systems are mixes between civil law and common law. Unlike in the past, mixed legal systems are nowadays seen by some as an independent legal family, which are by no means dying out and which are legal-culturally equal to common law and civil law. ${ }^{12}$ The best example of this novel epistemic move can be seen in the book edited by Vernon V. Palmer called Mixed Jurisdictions Worldwide. ${ }^{13}$ According to Palmer, the third legal family is 'conceived for purposes of convenience, utility, and explanatory power' and it can be used 'only if it provides better insights than comparative analysis has provided in the past'. ${ }^{14}$ In any case, for macro-comparative law, legal-cultural hybridity remains a problem of classification even though the phenomenon itself is hardly any novelty. ${ }^{15}$

\footnotetext{
${ }^{9}$ ibid 102.

${ }^{10}$ See, eg, Thomas Lundmark, Charting the Divide between Common and Civil Law (Oxford, Oxford University Press 2012).

${ }^{11}$ See Seán Patrick Donlan, 'Comparative Law and Hybrid Legal Traditions - an Introduction', in Eleanor Cashin-Ritaine, Seán Patrick Donlan, and Martin Sychold (eds), Comparative Law and Hybrid Legal Traditions (Lausanne, Swiss Institute of Comparative Law, 2010) 9-18 (arguing that hybridity challenges legal nationalism, positivism, centralism, and monism which are all part of the legal families approach).

${ }^{12}$ Husa (n 7) 215.

${ }^{13}$ Vernon Valentine Palmer (ed), Mixed Jurisdictions Worldwide: The Third Legal Family (Cambridge, 2 edn, Cambridge University Press 2012).

${ }^{14}$ Palmer, 'Introduction to the mixed jurisdictions' in ibid 16.

${ }^{15}$ See also Lundmark (n 10) 33-38 (discusses legal families and takes into account mixed legal systems). For an interesting discussion about legal history and hybridity, see Seán Patrick Donlan, 'Remembering: Legal Hybridity and Legal History' (2011) 2 Comparative Law Review 1 (pointing out that there are no pure types)
} 
The oldest of the classical mixed systems is probably that of Scotland because it was independent for a long time before it formed a Union named Great Britain (1707) with England and Wales Scotland had had connections with Continental law and, thus, assumed many Roman law/ius commune influences. Also, in the law of the province of Quebec in Canada there are similar features of mixed legal systems where common law has mixed with the civil law elements implanted earlier: branches like property law and civil law are of a French civil law type, but public law and criminal law are of a common law type. Besides, in Africa, common law has mixed with the customary law of the tribes and in Asia with a legal tradition that could, due to its cultural main features, be characterised as Confucian. ${ }^{16}$ Thus, there are many kinds of legal cultural hybridities and resulting legal pluralism.

In the same way, there are systems that belong to the family of Continental European law, for example in Latin America, Africa and Asia, where civil law has intermingled with common law. Crucially, European systems are these days so close to each other due to the European Union (EU) that some comparatists classify the EU law as a kind of mixed law containing elements from national systems (common law, civil law) mixed with public international law and sui generis EU elements. ${ }^{17}$ In comparative law view, the EU legal system is not a unitary entity but consists of different legal cultural elements, and in this sense it is a hybrid and needs to be studied as such. ${ }^{18}$

Some of the former socialist countries, too, are as a matter of fact in a state of mixed law although in Europe they mainly belong to the sphere of civil law. ${ }^{19}$ For example, Czech law is legal-culturally a complicated entity where remnants of socialist law (itself a Marxist variant of civil law) are still to be found in civil law, labour law and family law. On the other hand, in the Czech system commercial law is clearly Romano-Germanic. The earlier Czech picture has been further mixed by later legal loans from Western law and, due to this, the system is systematically fragmented and contains certain inconsistencies. Today, it is part of the EU, which has a huge impact on the law and legal culture of the Czech Republic. ${ }^{20}$ Because of all

\footnotetext{
${ }^{16}$ See, eg, Patrick H Glenn, Legal Traditions of the World: Sustainable Diversity in Law (Oxford, 5 edn, Oxford University Press 2014) ch 9.

${ }^{17}$ See, eg, Peter de Cruz, Comparative Law in a Changing World (London, 2 edn, Cavendish 1999) ch 5.

18 cf Paul James Cardwell and Tamara Hervey, 'Bringing in the Technical into the Socio-Legal' in David Cowan and Daniel Wincott (eds), Exploring the 'Legal' in Socio-Legal Studies (London, Palgrave 2016) 157$182 ; 166$.

${ }^{19}$ Husa (n 7) 216.

${ }^{20}$ See Bohumil Havel, 'The Czech Republic' in Jan Smits (ed), Elgar Encyclopedia of Comparative Law (Edward Elgar Publications 2012) 279-285.
} 
these reasons, it is difficult for the macro-comparatist to generalise and conceptualise systems that are mixed or undergoing a process of transformation from one legal family to another. ${ }^{21}$

To continue the above discussion, further examples of hybrids or mixed systems are South Africa where common law and Roman-Dutch law are combined and Malta that combines common law and Italian Continental law. Similar examples are the Philippines and Puerto Rico, both of which combine law of Spanish origin with common law. In addition, in practice also all Islamic systems are hybrids mixing Western, local and Muslim ingredients. ${ }^{22}$ Now, the purpose of this section is not to exhaustively list mixed legal systems but, rather, to provide an illustrative overview of various types of mixed legal systems so that the difficulties of macro-comparison become visible. As shown above, there are various mixtures and hybridities when it comes to the legal systems of the world. Nevertheless, it may be useful to note that the condition of being 'mixed law' or 'hybrid law' is not necessarily immutable, but there are differences between systems: some systems seem able to retain their constituent mixité, whereas others have a more endangered status as hybrid systems. These potential future developments are well presented and discussed in the recent book titled A Study of Mixed Systems. ${ }^{23}$ Correspondingly, the world of law is plural and this unorthodox plurality poses an epistemic problem for those who try to generalise and describe legal systems from the perspective of macro-comparison.

On the whole, different ingredients are mixed into different legal pluralistic entities depending on local applications and historical paths, like for instance colonialism. What results is normally a mix between various cultural ingredients combining Western and NonWestern, modern and traditional, religious and secular. Thus, for macro-comparative law these systems are epistemologically problematic because they are hard to conceptualise using vocabulary that is originally based on the distinction between civil law and common law. Hence, this is where metaphorical conceptualisation may become a useful tool as we will see in the following section.

\footnotetext{
${ }^{21}$ Simply, in many cases the macro-comparatist uses crude determining factors when systematising the legal systems of the world. A key factor has traditionally been the "fact that common law systems accept judge-made law as a source of law' (Lundmark (n 10) 49).

${ }^{22}$ See, eg, Farid S Shuaib, 'The Islamic Legal System in Malaysia' (2012) 21 Pacific Rim Law \& Policy Journal 85.

${ }^{23}$ Sue Farran, Esin Örücü and Seán Patrick Donlan (eds), A Study of Mixed Systems: Endangered, Entrenched or Blended (Farnham, Ashgate Publishing 2014).
} 


\section{Mixed legal systems and culinary metaphor}

It is important to realise that whatever one thinks of the classification of the world's legal systems and especially of mixed-legal systems it is an undeniable fact that some systems are hybrid as to their legal cultural nature. There is hybridity that cannot be explained away; some systems just are hybrid as to their nature. Typically these systems are more complex mixes than what is the case with the European mixes. For example, Morocco's system follows structurally and institutionally French models, yet its family law has modified but clear Islamic features. ${ }^{24}$ Or, to take another example, Mauritius' legal system has structurally and institutionally heavy British influences, whereas its civil law follows French models (the Code Napoleon, ie Code Civil) and there are also customary law elements included. ${ }^{25}$ And, this specific quality of hybridity makes them difficult to conceptualise in a standard comparative law language in a compelling and handy manner. Simply, we seem to have rather poorly fitting words (statutory law, case law, religious law, customary law etc) for the task. The reasons for this terminological inadequacy are not difficult to grasp.

Normally, a mixed legal system is the result of the transmigration of law and the outcome a mismatch between the recipient and the original model. In the resultant, ie the hybrid legal system, diverse legal elements co-exist simultaneously. ${ }^{26}$ And, therein lies the problem for macro-level description. Mixed ingredients are hard to generalise about and, furthermore, they are in a constant state of flux between differing legal cultural enticements. All this does not make it easy for a macro-comparatist to conceptualise mixed systems in a general and understandable manner. In brief, the question is this: how can we descriptively explain mixed systems in a concise and understandable manner? One possible answer is to rely on metaphorical conceptualisation; the usage of metaphor may open up new ways of understanding and studying various legal mixtures. ${ }^{27}$

\footnotetext{
${ }^{24}$ See, eg, Katie Zoglin, 'Morocco's Family Code: Improving Equality for Women’ (2009) 31 Human Rights Quarterly 964.

${ }^{25}$ See, eg, AH Angelo, 'Mauritius: The Basis of the Legal System' (1970) 3 Comparative and International Law Journal of Southern Africa 228.

${ }^{26}$ Esin Örücü, 'Law as Transposition' (2002) 51 International and Comparative Law Quarterly 205, 212.

27 This point is also made by Cardwell and Hervey (n 17) 164 in the context of EU law.
} 
Basically, the problem of macro-comparative law's mainstream approach is that its presentations of mixed legal systems are not very imaginative, and they lack certain intellectual appeal and gravity. Anyone who reads comparative law literature soon finds out that mixed legal systems are kind of a remainder of an attempt to classify and characterise the world's legal systems from a macro-comparative viewpoint. For these reasons, Örücü's discussion of mixed legal systems through the use of culinary metaphors is particularly interesting because they simplify an otherwise tremendously complicated subject matter. Regardless of complexity, these metaphors give an instant feeling of being spot on because they convey an intuitively proper general mental image. In other words, they tell a story of a legal system with a minimal amount of words. Hence, metaphor is a narrative compressed into a linguistically minimal space. Moreover, it would seem, the use of culinary metaphor makes this kind of macro-comparative law analysis more personal and memorable. And, no doubt, also intellectually more appealing to many readers who are jaded with boring and dull descriptive macro-comparative law texts focusing on positive laws and the so-called Great legal families ${ }^{28}$ It is almost needless to say that comparative law literature is filled with common-law-this and civil-law-that discussions and descriptions. Metaphor may be a way out.

Basically, Örücü has distinguished between four different kinds of mixed legal systems which are: 1) mixing bowl systems where distinct elements are integrated within similar legal institutions, 2) salad bowl systems where both legal elements and institutions are distinct, 3) salad plate systems where there is legal dualism or pluralism and 4) purée systems where legal traditions that form the basis for legal elements and institutions have become genuinely blended. ${ }^{29}$ This metaphorical structure uses the level of integration as the foundation: at one end there is a mixing bowl where legal elements are interacting but not totally blended, at the other end there is a purée where legal elements are truly fused together making it difficult to distinguish between them. In practice, however, most mixed systems are situated somewhere in between these extreme ends.

\footnotetext{
${ }^{28}$ For a recent discussion of legal families see Mariana Pargendler, 'The Rise and Decline of Legal Families' (2012) 60 American Journal of Comparative Law 1043 and Jaakko Husa, 'The Future of Legal Families' (Oxford Handbooks Online May 2016) DOI: 10.1093/oxfordhb/9780199935352.013.26

29 Örücü (n 25) 213. For more detailed earlier discussion, see Esin Örücü, 'Mixed and Mixing: A Conceptual Approach', in Esin Örücü and Elspeth Attwooll and Sean Coyle (eds), Studies in Legal Systems: Mixed and Mixing (The Hague, Kluwer 1996) 335-351.
} 
On one occasion, Örücü visualises mixed systems along a spectrum and continues by conceptualising her culinary mixed legal system metaphor in the following manner:

When elements from socio-culturally similar and legal-culturally different legal systems come together forming mixed systems of the already mentioned 'simple' kind the 'mixing bowls' - the ingredients are still in the process of blending but in need of further processing if a 'purée' is to be produced. Next to 'simple' mixes come the 'complex' mixed systems, where the elements are both socio-culturally and legalculturally different. I have called this type elsewhere the 'Italian salad bowl' where, although the salad dressing covers the salad, it is easy to detect the individual ingredients clearly through the side of the glass bowl. A good example of this is Algeria. Then, there is what I called the 'English salad plate', the ingredients sitting separately far apart on a flat plate with a blob of mayonnaise at the side into which the different ingredients can be dipped before consumption. Examples of this are the Sudan and Zimbabwe - legal pluralisms -, which lie towards the far end of the spectrum. The examples become more extreme along the path, ending in 'curdling', with a dysfunctional legal system, as already mentioned. ${ }^{30}$

To be sure, this is not a boring way to write about macro-comparative law. Undoubtedly, it is also a personal and memorable way to conceptualise legal hybridity. Albeit, the question is: does this kind of metaphorical composing really work? And, if it works what makes it work?

As one can see from the above lengthy quote, the culinary metaphor is really about explaining how socio-culturally and legal-culturally different legal elements form mixed outcomes of various kinds. Essentially, culinary metaphors are not important as such but, rather, they are a means to an end. Accordingly, the macro-comparative compressed narrative told by the help of a metaphor transfers words describing legal elements (institutions, sources, processes, actors etc) into culinary ones so that 'salad bowl' and other words enable the reader to conceive the described world of law in terms of dishes. But what really takes place here? What happens is that this metaphor actually stimulates the reader to visualise a mixed legal system because these non-conventional words (in a conventional legal context) awaken the reader's perception into a form of imagery - mixed legal system X transforms into mental representation of a salad bowl of law or into a salad plate of legal institutions. In this process of metaphorising, the abstract macro-comparative terms and concepts become legal theoretical grand-scale images enabling the reader to instantly picture what they are

\footnotetext{
30 The quote is taken from Esin Örücü, 'What is a Mixed Legal System: Exclusion or Expansion?' (2008) 12 Electronic Journal of Comparative Law <www.ejcl.org/121/art121-15.pdf> accessed 24 May 2016.
} 
reading and also to remember and, at best, instantly conceive what they are reading. ${ }^{31}$ By the same token, culinary metaphor is also an allusion because it draws on sources relating to a kitchen or cookery, which are outside the world of law and the sphere of legal systems.

For example, mentally visualising Scots law as a mixing bowl where there are distinct civil law and common law elements integrated with similar legal institutions, is an intellectually clever manner of expressing the overall state and nature of Scots law as a mixed legal system. In short, the whole point in this kind of use of metaphor is to create a mental image that enables quick understanding of a complicated thing. ${ }^{32}$ For an attempt to grasp and generalise hybrid systems comparatively this kind of understanding may be particularly beneficial. Under these circumstances, metaphor is a comparative generalisation that makes complicated mixed systems cognitively less complex, ie metaphorising is an act of epistemic simplification - something which is always crucial for macro-comparative law. ${ }^{33}$

Moreover, the fact that metaphor fits so well in theoretically-oriented comparative law writing should not be a surprise for anyone. Along similar lines, I agree with Finn Makela when he claims that legal scholars who venture beyond the doctrinal study of law 'tend to think of themselves as engaging in some form of social science or philosophy. As such, we tend to view metaphors with some suspicion'. But as he continues, metaphor may be a powerful methodological tool for generating new understanding. ${ }^{34}$ Moreover, we can argue that legal language in general is strongly metaphorical because law is 'an abstract and intellectually-indeterminate idea', and as such we need 'to describe it in figurative words and phrases that evoke concrete and readily-comprehensible sensory phenomena', ${ }^{35}$

\footnotetext{
${ }^{31}$ This kind of understanding of a text is metaphorical as it relies on the use of non-literal meaning which is connected to the context of the text. So, "the word is always the bearer of the "emergent meaning" which specific contexts confer upon it', Paul Ricoeur, in John B. Thompson (ed), Hermeneutics \& the Human Sciences, (New York, Cambridge University Press 1995) 166. Clearly, the specific context in this case is macrocomparative law in general and discourse on mixed legal systems in particular.

${ }^{32}$ I have argued elsewhere that this kind of function is an elemental part of the concept of 'legal family', which is also a metaphorical device used to conceptualise complicated things. See Jaakko Husa, 'Family Affair Comparative Law's Never Ending Story?' Annuario di diritto comparato e di studi legislativi (Napoli, Edizioni Scientifiche Italiani 2014) 21-48.

${ }^{33}$ One could also argue that, in fact, reality is metaphorical so that metaphor forms a kind of a bridge which traverses the cognitive gap between the scholar and reality. See Gary Watt, 'The Matter of Metaphor in Language and Law' (2012) 6 Pólemos 49.

${ }^{34}$ Makela (n 5) 415.

${ }^{35}$ Bernard J Hibbits, 'The Metaphor is the Message' (1995) 22 International Journal for the Semiotics of Law 53; 53.
} 
Now, the culinary macro-comparative metaphor used by Örücü implies that metaphor functions as a methodological tool generating new understanding (ie as an act of perceiving) by creating mental images of different kinds of mixed legal systems. ${ }^{36}$ This kind of a metaphor is profoundly innovative as to its nature or what Paul Ricouer calls 'a momentary creation of language... which does not have a status in the language as something already established'. ${ }^{37}$ Importantly, metaphors are built of creative composing that invites the reader along a journey of understanding (foreign law) with the author. ${ }^{38}$ In the end, metaphorical writing contributes to an imaginative comparative law that finds its own ways of doing things, and it does this without relying too much on the conceptual help from other disciplines that may be alien to the hermeneutical character of the comparative study of law. ${ }^{39}$

\section{Conclusion}

As shown above, it can be concluded that metaphorical writing has merits in non-doctrinal comparative law writing. In an essential sense, macro-comparative culinary metaphors are legal theoretical images and, as noted by Maks Del Mar, these kinds of images allow theoretical constructions to be built, so in this sense metaphors are 'constructive; like islands of belief dotting the oceans of doubt' ${ }^{40}$ And, often comparatists are indeed sailing in an ocean of doubt caused by the epistemic challenges posed by hybrid legal systems. Ultimately, metaphors are helpful precisely because they provide islands of belief but also, crucially, they provide points of understanding - making cognitively sense of foreign legal systems and legal hybridities. ${ }^{41}$ This core task of making sense of the foreign lies at the heart of comparative law as an academic discipline.

\footnotetext{
${ }^{36}$ However, metaphorical language can also be used in a doctrinal sense so that it frames 'the world in ways which are presented as unquestionable' as has been the case with EU law, Cardwell and Hervey (n 17) 174. Yet, Örücü's metaphors seem more open-ended and clearly far less unquestionable as to their nature.

${ }^{37}$ Ricoeur, Hermeneutics and the Human Sciences (n 30) 174.

${ }^{38}$ In a more general view, we might argue that the literary model (which metaphorical expression follows) has a contribution to make to comparative law as one tool in the comparatist's toolbox. See Eric Heinze, 'The Literary Model in Comparative Law' (2014) 9 Journal of Comparative Law 17, 27.

${ }^{39}$ However, it would be a mistake to think that any metaphor would work. It is clear that foreign legal texts cannot be freely interpreted or metaphorised because they present 'a limited field of possible constructions' as reminded by Paul Ricouer, Interpretation Theory: Discourse and the Surplus of Meaning (Forth Worth, Texas Christian University Press 1976) 79.

${ }^{40}$ Maksymilian Del Mar, 'Thinking in Images in Legal Theory', in Maksymilian Del Mar and Claudio Michelon (eds), The Anxiety of the Jurist (London, Routledge 2013) 43-57; 64.

${ }^{41}$ It is likely that metaphorical use of legal language is also 'a potent constitutive mechanism for creating and sustaining communities, including legal communities’ as noted by Cardwell and Hervey (n 17) 157.
} 
Altogether, the use of metaphor in comparative law has many benefits of which some are even quintessential as to their nature. ${ }^{42}$ One of most crucial dimensions relates to the nature of comparative law research. Basically, comparative knowledge produced by the comparatist is typically relative as to its nature. This is to say that there is no certain knowledge but that the research results are well founded interpretations rather than fully objective scientific results. ${ }^{43}$ So, while using metaphors, comparatists have in fact revised the absolute knowledge claim of metaphors in the comparative study of law. Of course, recognition of the use of metaphorical language is also about accepting the interpretative character of comparative law research in general. ${ }^{44}$ If we accept this view, then, metaphors are strictly speaking non-scientific (as in an exact science) but at the same time are rather intrinsic to constitutive forms in constructing our hermeneutic knowledge of foreign legal systems. ${ }^{45}$ But to claim that metaphor is not scientific is not to undermine its value, on the contrary, because 'law is a major area in which reality is metaphorical' as Gary Watt notes. ${ }^{46}$

Along these lines, the function of metaphors is not really to explain the differences and similarities found in scholarship. Instead, it is to offer holistic projections that help comparatists to understand their subject matter and to make it easier for readers to grasp the essential message (in the form of mental images) which the comparatist seeks to convey. In other words, metaphor constructs a resemblance of two different objects relying on some common characteristics ie metaphor is comparison inside comparison. On balance, there is one significant problem when it comes to using these kinds of macro-comparative metaphors. It seems, I believe, that most or at least many readers will epistemically benefit from macrocomparative metaphors by creating instant legal theoretical images when reading, but this is not necessarily so for all of the readers. In short, there may be readers who do not form such mental images naturally. And, of course, for such readers heavy reliance on metaphors may become dramatically counterproductive. Simply, not everyone visualises in the form of mental imagery and understands in the form of picture-like representations. Moreover,

\footnotetext{
${ }^{42}$ Watt goes further and argues that 'law as cultural ordering may be considered to be a reflection of the internal ordering of the mind' Watt (n 32) 62.

${ }^{43}$ See for more detailed discussion, Mark Van Hoecke, 'Methodology of Comparative Legal Research' (2015) 5 Law and Method (available: <www.bjutijdschriften.nl/tijdschrift/lawandmethod/2015/12/RENM-D-14-00001>).

${ }^{44}$ See also John Bell, 'Legal Research and the Distinctiveness of Comparative Law', in Mark Van Hoecke (ed.) Methodologies of Legal Research (Oxford, Hart Publishing 2011) 155-176.

${ }^{45}$ See also Husa (n 7) 61 (discussing the scholarly nature of comparative law research).

${ }^{46}$ Watt (n 32) 63.
} 
metaphors may also confuse readers because they are necessarily imperfect as to their nature, ie they are able to cover certain aspects but certainly not all. ${ }^{47}$ Of course, this limitation concerns also Örücü's metaphors. And, it goes without saying that failed metaphors end up obscuring things and prevent understanding as cognitive obstacles. Accordingly, Cicero's ancient warning about the use of metaphor is good to bear in mind: 'A metaphor is a short form of simile, contracted into one word; this word is put in a position not belonging to it as if it were its own place, and if it is recognizable it gives pleasure, but if it contains no similarity it is rejected. ${ }^{48}$ It remains the responsibility of a comparatist to make sure that metaphor contains a sufficient degree of similarity or it will be rejected.

One final thought. For most readers macro-comparative metaphors probably work well, but relying too extensively or too imaginatively on metaphors may be over the top, thus turning this otherwise useful comparative device into scholarly coquetting which nobody really benefits from. As the ancient carving in Apollo's temple in Delphi says 'nothing in excess' and that works well with the use of metaphors in comparative law too. ${ }^{49}$

\footnotetext{
${ }^{47}$ As such this is perfectly normal and a part of the macro-comparative endeavour, see Husa (n 31).

${ }^{48}$ Cicero, De Oratore III 157, in AS Wilkins (ed), Libri de oratore tres (Oxonii (Oxford), E Typographeo Clarendoniano (Clarendon Press) 1902) (source: Perseus Digital Library, http://perseus.tufts.edu. 'Similitudinis est ad verbum unum contracts brevitas, quod verbum in alieno loco tanquam in suo positum si agnoscitur, delectat, si simile nihil habet, repudiatur'. Cicero spoke of a chain of metaphorical words used to describe something as 'a valuable stylistic ornament' (De Oratore III 167; 'magnum ornamentum orationis'). Yet, Cicero also cautioned the users of this ornament and warned them to avoid obscurity.

${ }^{49}$ In classical Greek upper case letters 'MH $\triangle \mathrm{EN}$ AГAN' (in lower case $\mu \eta \delta \dot{\varepsilon} v \alpha$ ó $\left.\gamma \alpha v\right)$. For a short explanation, see Casper J. Kraemer, Jr., 'MHАEN АГAN: An Additional Note’ (1927) 22 Classical Philology 223.
} 